\title{
THE STIMULATION OF BIOLUMINESCENCE IN PHOTOBACTERIUM LEIOGNATHI AS A POTENTIAL PRESCREEN FOR ANTITUMOR AGENTS
}

\author{
Deborah A. Steinberg*, Gail A. Peterson, Richard J. White \\ and William M. MAIESE \\ Infectious and Neoplastic Disease Research Section \\ Medical Research Division, American Cyanamid Company, Lederle Laboratories, \\ Pearl River, New York 10965, U.S.A.
}

(Received for publication June 29, 1985)

\begin{abstract}
The stimulation of bioluminescence in Photobacterium leiognathi has previously been described as a test for genotoxic compounds. An adaptation of this procedure has been developed which uses a dim variant of $P$. leiognathi and permits the prescreening of microbial fermentation broths for potential antitumor agents. Bioluminescence in this organism was stimulated by compounds which bind to DNA or affect DNA synthesis. Antibiotics with target sites such as protein, cell wall or RNA synthesis, did not alter bioluminescence. Fermentation broths from over 5,000 soil isolates were prescreened in this assay and $95(1.6 \%)$ were defined as active. Further analysis of selected cultures suggested that about half produced compound(s) with DNA-binding activity. These results suggest that the photobacterium induction assay (PIA) may be useful as a prescreen for potential antitumor agents. The assay is rapid, simple and requires only microgram quantities of material for testing.
\end{abstract}

A variety of in vitro test systems has been developed to detect the presence of secondary metabolites in microbial fermentation broths that have potential as anticancer agents ${ }^{1,2)}$. Active compounds selected by these prescreens are subsequently progressed to an in vivo screen such as a transplantable murine tumor. Most of the currently used anticancer drugs are considered to exert their cytotoxic activity via an effect on $\mathrm{DNA}^{3)}$. Indeed, many are mutagenic, carcinogenic, or both in microbial and animal test systems ${ }^{4,5}$. Several prescreens have been based on this association between anticancer activity and a compound's ability to interact with or damage DNA, e.g. the biochemical induction assay $^{6)}$. A number of recent studies have focused on the effect of genotoxic agents on bacterial bioluminescence ${ }^{7 \sim 10)}$. Of special interest in these assays are the dim variants which exhibit increased bioluminescence upon exposure to such agents. Although there is evidence that bacterial bioluminescence is an inducible system, the mechanism for chemical induction of bioluminescence in these organisms is not known ${ }^{11)}$.

In this report, we describe the development of a rapid, sensitive microbiological prescreen which uses a dim variant of Photobacterium leiognathi to detect potential antitumor compounds that bind to or affect DNA by means of increased bioluminescence.

\section{Materials and Methods}

Bacterial Strains

A wild type strain of $P$. leiognathi was obtained from American Type Culture Collection (ATCC 27561) and deposited in the Lederle stock collection as RC93. RC93-2 was a spontaneous dim variant of RC93 selected for use in the photobacterium induction assay (PIA). 


\section{Media}

The medium used for bacterial growth (731-A) was the same as ATCC 731 except that the $\mathrm{CaCO}_{3}$ was omitted. 731-A contained $\mathrm{NaCl} 30.0 \mathrm{~g}, \mathrm{~K}_{2} \mathrm{HPO}_{4} 3.9 \mathrm{~g}, \mathrm{KH}_{2} \mathrm{PO}_{4} 2.1 \mathrm{~g}, \mathrm{NH}_{4} \mathrm{Cl} 5.0 \mathrm{~g}$, yeast extract (Difco) $5.0 \mathrm{~g}$, Bacto-Tryptone (Difco) $5.0 \mathrm{~g}, 1 \mathrm{M}$ Tris buffer pH $7.550 .0 \mathrm{ml}$, glycerol $3.0 \mathrm{ml}$, and $\mathrm{KCl}$ $0.75 \mathrm{~g}$ in 1 liter of distilled water. The $\mathrm{pH}$ was adjusted to 7.2 before autoclaving and $4.0 \mathrm{ml}$ of $\mathrm{MgSO}_{4} \cdot 7 \mathrm{H}_{2} \mathrm{O}(25 \% \mathrm{w} / \mathrm{v})$ were added aseptically after sterilization. Agar was added to a final concentration of $1.5 \%(\mathrm{w} / \mathrm{v})$ for use in culture plates and $1 \%$ for use in base layers or in seeded overlays.

\section{Chemicals}

Acriflavine, proflavine, ethidium bromide, and nalidixic acid were obtained from Sigma Chemical Co. Antitumor antibiotics were obtained from Dr. D. Borders, Medical Research Division, American Cyanamid Company, Lederle Laboratories. All other compounds were purchased as SensiDiscs from Baltimore Biological Laboratories (BBL).

\section{Photobacterium Induction Assay (PIA)}

A schematic diagram of the PIA is given (Fig. 1). Briefly, RC93-2 was grown in 731-A, diluted 1: 1 with glycerol, and then stored at $-70^{\circ} \mathrm{C}$. A fresh, overnight culture was prepared by scraping the surface of the contents of a frozen vial, streaking the organism onto 731-A agar, and incubating the culture plate for $16 \sim 24$ hours at $30^{\circ} \mathrm{C}$. A single colony was used to inoculate $10 \mathrm{ml}$ of 731 -A broth in a $50-\mathrm{ml}$ flask. The culture was aerated by shaking at $30^{\circ} \mathrm{C}$, and absorbance was monitored with an

Fig. 1. Schematic representation of photobacterium induction assay.

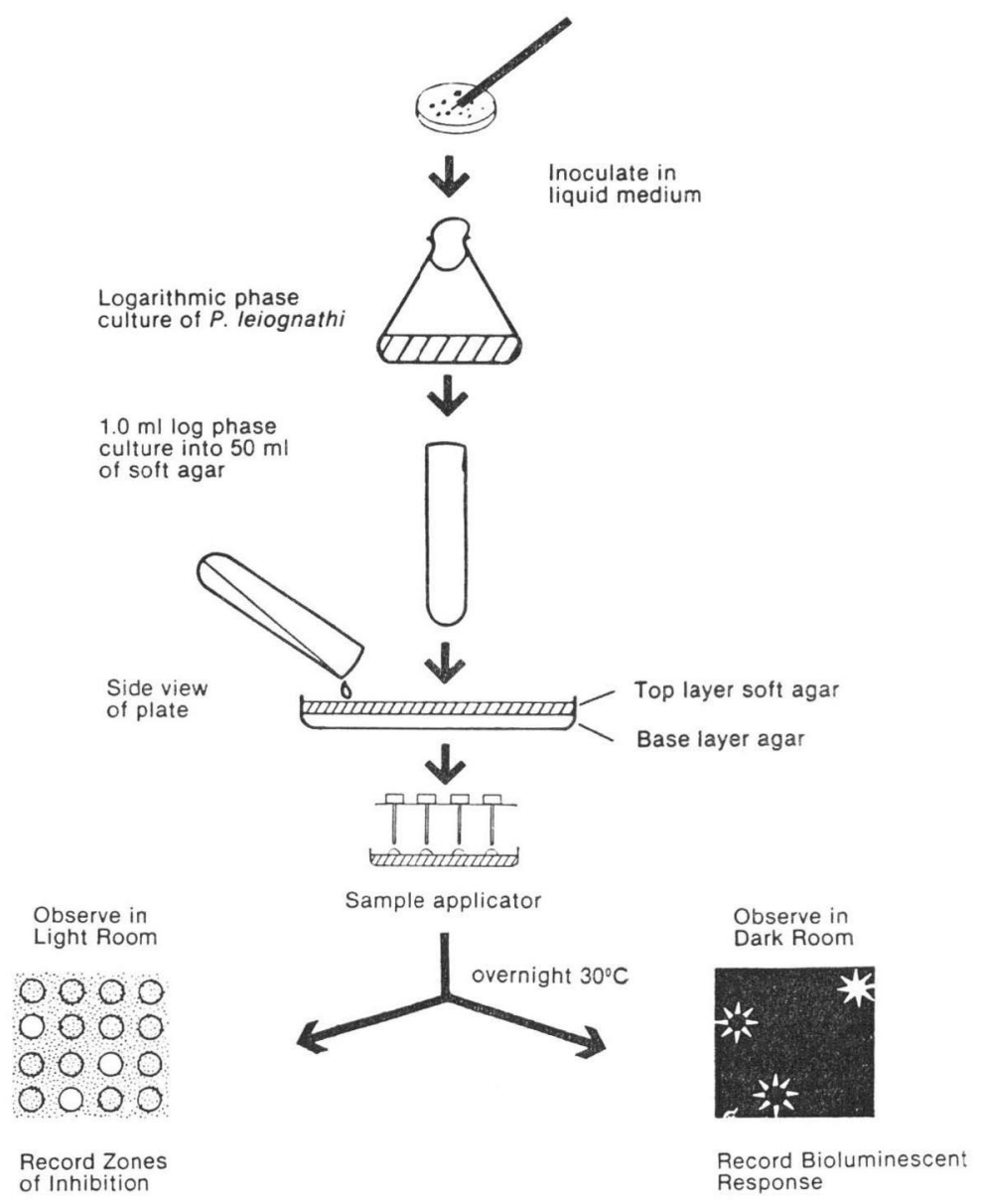


LKB Ultrospec (Model 4050-011). At an $\mathrm{A}_{880}=0.5$ unit, a $1.0 \mathrm{ml}$ sample of this culture was used to inoculate a $50-\mathrm{ml}$ overlay $\left(45^{\circ} \mathrm{C}\right)$ which was immediately poured onto a $100-\mathrm{ml}$ base layer in a 23 $\mathrm{cm}^{2}$ Nunc Bioassay Dish (240835). After the overlay solidified, BBL Sensi-Discs or paper disks (6.35 mm; Schleicher and Schuell) containing $25 \mu \mathrm{l}$ of sample solutions were applied to the agar surface. The plates were incubated $16 \sim 18$ hours at $30^{\circ} \mathrm{C}$, then scored for antimicrobial activity under normal light conditions. The plates were then examined in a light tight room and, after allowing for adjustment of one's eyesight to the dark, the bioluminescent responses were assessed relative to controls. Permanent records were obtained by photographing the plates in the absence of light using a Nikon

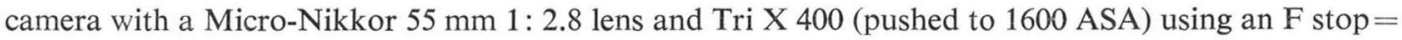
2.8 , and a 3-minute exposure.

\section{Assay for Drug-DNA Interaction}

Herring testes DNA (Sigma) was prepared as a $10 \times$ stock in TE buffer $(10 \mathrm{~mm}$ Tris, pH 8.0; $1 \mathrm{~mm}$ EDTA, $\mathrm{pH} 8.0$ ) and then incorporated directly into the agar at $1 \mathrm{mg} / \mathrm{ml}$. Various compounds were then analyzed in the PIA as described above. Proflavine $(25 \mu \mathrm{g} /$ disk $)$, which intercalates DNA base pairs, served as a positive control. Nalidixic acid $(2.5 \mu \mathrm{g} /$ disk $)$, which does not interact with DNA directly, was used as a negative control.

\section{Results}

\section{PIA Activity of Known Compounds}

A number of compounds with different biochemical target sites was evaluated (Table 1). The concentration given for active compounds indicates the minimum amount required to stimulate bioluminescence above background. Compounds were considered inactive if they failed to stimulate bioluminescence at the maximum concentration tested. Agents which inhibited protein, RNA or

Table 1. Compounds evaluated in the PIA.

\begin{tabular}{|c|c|c|c|c|}
\hline & Compound & $\begin{array}{l}\text { Concentration } \\
(\mu \mathrm{g} / \text { disk })\end{array}$ & $\begin{array}{c}\text { Growth } \\
\text { inhibition } \\
(\mathrm{mm})\end{array}$ & $\begin{array}{c}\text { PIA } \\
\text { response }^{\mathrm{a}}\end{array}$ \\
\hline \multirow[t]{3}{*}{ Intercalating dyes } & Acriflavine & 6.3 & 0 & + \\
\hline & Proflavine & 2.5 & 0 & + \\
\hline & Ethidium bromide & 6.3 & 0 & + \\
\hline \multirow{3}{*}{$\begin{array}{l}\text { DNA synthesis } \\
\text { inhibitors }\end{array}$} & Nalidixic acid & 2.5 & 16 & + \\
\hline & Cinodine & 0.8 & 0 & + \\
\hline & Novobiocin & 30 & 18 & - \\
\hline \multirow{6}{*}{$\begin{array}{l}\text { Protein synthesis } \\
\text { inhibitors }\end{array}$} & Clindamycin & 2 & 0 & - \\
\hline & Erythromycin & 15 & 10 & - \\
\hline & Tetracycline & 30 & 23 & - \\
\hline & Gentamicin & 10 & 10 & - \\
\hline & Streptomycin & 10 & 10 & - \\
\hline & Chloramphenicol & 30 & 27 & - \\
\hline \multirow{4}{*}{$\begin{array}{l}\text { Cell wall synthesis } \\
\text { inhibitors }\end{array}$} & Penicillin & 100 & 0 & - \\
\hline & Ampicillin & 10 & 0 & - \\
\hline & Cefamandole & 30 & 22 & - \\
\hline & Vancomycin & 30 & 0 & - \\
\hline \multirow{4}{*}{$\begin{array}{l}\text { Miscellaneous } \\
\text { antibiotics }\end{array}$} & Nystatin & 100 units & 0 & - \\
\hline & Sulfachloropyridazine & 250 & 16 & - \\
\hline & Sulfathiazole & 250 & 0 & - \\
\hline & Rifampin & 5 & 15 & - \\
\hline
\end{tabular}

a + : Active at minimum concentration indicated. - : Inactive at maximum concentration tested. 
Table 2. Antitumor antibiotics evaluated in the PIA.

\begin{tabular}{|c|c|c|}
\hline & $\begin{array}{l}\text { Concentration } \\
(\mu \mathrm{g} / \text { disk })\end{array}$ & $\begin{array}{c}\text { Growth } \\
\text { inhibition } \\
(\mathrm{mm})\end{array}$ \\
\hline \multicolumn{3}{|l|}{ Active compounds ${ }^{a}$} \\
\hline Bleomycin & 25 & 0 \\
\hline Hedamycin & 25 & 0 \\
\hline Mitomycin $\mathrm{C}$ & 1.6 & 8 \\
\hline Netropsin & 1.6 & 0 \\
\hline Ravidomycin & 25 & 13 \\
\hline Streptonigrin & 0.02 & 0 \\
\hline Streptozotocin & 0.05 & 0 \\
\hline Trioxacarcin & 12.5 & 9 \\
\hline \multicolumn{3}{|l|}{ Inactive compounds ${ }^{\mathrm{b}}$} \\
\hline Actinomycin D & 25 & 10 \\
\hline Anthramycin & 25 & 12 \\
\hline Carminomycin & 25 & 8 \\
\hline Chromomycin & 25 & 0 \\
\hline Copiamycin & 25 & 0 \\
\hline Doxorubicin & 25 & 0 \\
\hline 5-Fluorouracil & 25 & 21 \\
\hline Largomycin & 25 & 0 \\
\hline Mithramycin & 25 & 0 \\
\hline Neocarzinostatin & 25 & 0 \\
\hline Saframycin & 25 & 9 \\
\hline
\end{tabular}

cell wall synthesis were not active in the PIA. With the exception of novobiocin, all of the tested compounds known to interact with DNA or inhibit DNA-related processes were active in the PIA. Various antitumor antibiotics were also tested in the PIA (Table 2). All of the active compounds interact directly with DNA. However, several other drugs with known DNA interactions were not detected by the PIA.

\section{Determination of DNA-drug Interactions}

A secondary assay was developed to determine if the PIA activity of an unknown compound resulted from direct or indirect interactions with DNA. Exogenous herring testes DNA was used to determine if the compounds could bind to DNA. Presumably, once bound to exogenous DNA, drugs would become unavailable and the bioluminescent response in the PIA would, therefore, be diminished or eliminated. Proflavine was selected as a positive control in the DNA-binding assay, whereas nalidixic acid served as a negative control. The amount of DNA required to effectively diminish PIA activity is determined by the number of molecules of drug which can bind per nucleotide base pair. DNA (1 $\mathrm{mg} / \mathrm{ml})$ was required to maximize the reduction of the bioluminescent response to proflavine (Fig. 2). Approximately one molecule of proflavine binds per 2.5 base pairs ${ }^{3)}$. This molar ratio translates into a weight: weight ratio of $1: 6$ for proflavine: DNA. Thus, $150 \mu \mathrm{g}$ of DNA binds $25 \mu \mathrm{g}$ of proflavine. The PIA response to netropsin, an antitumor antibiotic that binds avidly to the 
Fig. 3. Evaluation of microbial fermentation broths in the PIA.

A large assay plate containing samples of 80 fermentation broths was photographed in the light (a) and dark (b). Netropsin (N) $25 \mu \mathrm{g} /$ disk served as a control. Three fermentation broths (arrows) appeared active on this plate.
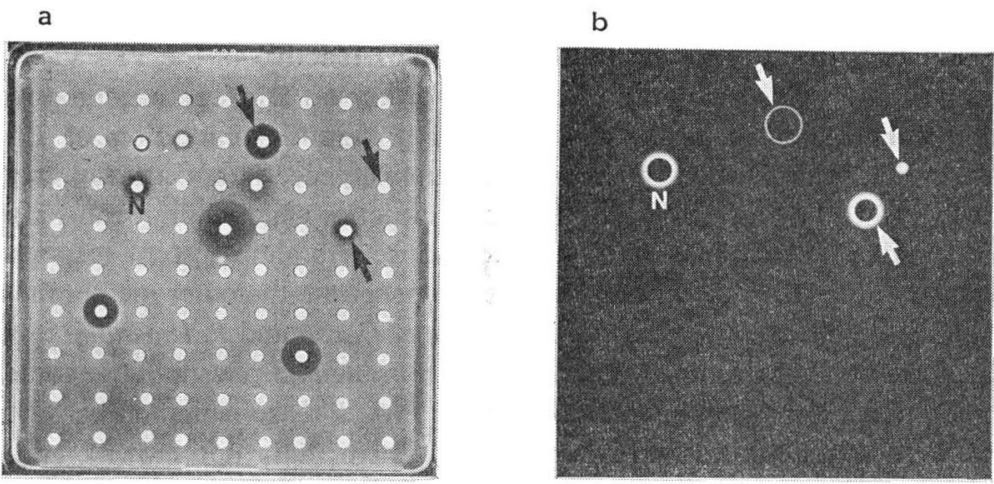

minor groove of DNA, was also reduced by the presence of exogenous DNA ${ }^{12)}$. As expected, the presence of DNA had no effect on the bioluminescent ring around nalidixic acid.

\section{Evaluation of Fermentation Broths for PIA Response}

Netropsin, a typical natural product and known antitumor antibiotic, was used as a positive control in the PIA when prescreening microbial fermentation broths for potential antitumor agents. A bright area of bioluminescence appeared around the netropsin disk (Fig. 3). Samples that stimulated bioluminescence to a similar degree as netropsin were considered active. Of the three active fermentation broths indicated (arrows), one was later shown to contain netropsin, whereas the active component(s) of the two remaining broths have not yet been identified.

Of the 5,760 soil isolates that were analyzed, fermentation broths from $95(1.6 \%)$ were active in the PIA. After further analysis of the active broths, thirteen were selected for purification and chemical identification based on the reproducibility of the fermentation and bioluminescent response. Seven of the thirteen ( $54 \%$ ) exhibited a DNA-binding activity and all of these contained netropsin. The remaining broths are currently under investigation.

\section{Discussion}

A photobacterium induction assay (PIA) has been used to prescreen microbial metabolites for potential antitumor activity. Other applications of bacterial bioluminescence have exploited different species of Photobacterium to identify chemicals as mutagenic or carcinogenic agents ${ }^{7,0)}$. Dim variants of $P$. phosphoreum and $P$. leiognathi express increased bioluminescence upon exposure to genotoxic agents. The sensitivity of these assays compares favorably with that of the AMES test ${ }^{4}$. The presence of a highly active P-450 cytochrome system in Photobacterium obviated the need for microsomal activation of certain procarcinogens (e.g. 20-methylcholanthrene) as is required for their detection in the AmEs assay ${ }^{8}$. Although the exact mechanisms for the increased bioluminescence is unknown, it has been suggested that exposure of the dim variant to strong mutagens (e.g. $N$-methyl- $N$-nitro- $N$ 'nitrosoguanidine) results in the appearance of stable, bright forms of the organism. Presumably, a permanent change in the DNA has been effected which restores the wild type level of bioluminescence. Although the mechanism for the transient, phenotypic reversion induced by intercalating dyes or inhibitors of DNA synthesis is unknown, there is evidence that suggests de novo protein synthesis is re- 
quired for the bioluminescent response ${ }^{10,13)}$.

The analysis of known compounds in the PIA compared favorably with the sensitivity and predictability of another in vitro test for antitumor agents, the biochemical induction assay (BIA) ${ }^{8)}$. In the latter, compounds which bind to DNA or inhibit DNA synthesis induce a $\lambda$ placZ prophage in Escherichia coli. With the exception of netropsin, all of the tested antitumor agents that were active in the PIA are active in the BIA ${ }^{2)}$. Of those compounds inactive in the PIA (Table 2), only $25 \%$ were inactive in the BIA. This difference in detection of known DNA active compounds, such as actinomycin D and mithramycin, may result from their preferential inhibition of RNA synthesis ${ }^{14)}$. Although the exact mechanism of the stimulated bioluminescence is not known, continued synthesis of luciferase is believed to be required ${ }^{10,13)}$. Hence, antibiotics which inhibit transcription in addition to their DNA damaging activity may be unable to induce a bioluminescent response. Compounds may also be inactive in the PIA due to their inability to penetrate the outer membrane of $P$. leiognathi. A recent study on the biochemistry of the cell envelopes of $E$. coli and $P$. leiognathi reveals a significant difference between the two organisms in their outer membrane and phospholipid content ${ }^{15}$ ).

When fermentation broths were prescreened in the PIA, a reasonable number $(1.6 \%)$ were active. These broths were subsequently analyzed in the BIA system (data not shown), and $10 \%$ were BIA positive. The preliminary characterization of several broths suggested DNA-binding activity in that their PIA activity was prevented by the addition of exogenous DNA. These data support the hypothesis that bioluminescence of the dim variant of $P$. leiognathi is stimulated by agents that interact with DNA in a direct as well as in an indirect fashion. Although bioluminescence can be quantitated, the procedures are time consuming and unable to handle a large number of samples. The ability of the PIA to prescreen thousands of samples rapidly and reproducibly makes this type of prescreen more amenable to current preclinical programs. We conclude that the PIA is a specific screen capable of detecting potential antitumor agents through their interaction with DNA. The difference in selectivity between the PIA and BIA further suggests that this test can be applied to large-scale screening for new anticancer agents that may not be detected in other currently used prescreens.

\section{References}

1) White, R. J.: Microbiological models as screening tools for anticancer agents: Potentials and limitations. Ann. Rev. Microbiol. 36: 415 433, 1982

2) White, R. J. \& W. M. MAIESE: Detection of microbial metabolites with antitumor activity. In Progress in Industrial Microbiology. Ed., M. E. BusheLL, pp. $167 \sim 189$, Elsevier, New York, 1983

3) Corcoran, J. W. \& F. E. Hahn, Eds.: Antibotics. III. Mechanism of Action of Antimicrobial and Antitumor Agents. Springer-Verlag, Berlin, 1974

4) McCann, J. \& B. Ames: Detection of carcinogens as mutagens in the Salmonella/microsome test: Assay of 300 chemicals. Proc. Natl. Acad. Sci. U.S.A. 72: 5135 5139, 1976

5) Sieber, S. M. \& R. H. Adamson: The clastogenic, mutagenic, teratogenic and carcinogenic effects of various antineoplastic agents. In Pharmacological Basis of Cancer Chemotherapy. pp. $401 \sim 468$, Williams \& Wilkins, Baltimore, Maryland, 1975

6) Elespuru, R. K. \& R. J. White: Biochemical prophage induction assay: A rapid test for antitumor agents that interact with DNA. Cancer Res. 43: 2819 2830, 1983

7) Ulitzur, S.; I. Weiser \& S. Yannai: A new sensitive and simple bioluminescence test for mutagenic compounds. Mutat. Res. 74: 113 126, 1980

8) Ulitzur, S.; I. Weiser \& S. YannaI: Bioluminescence test for mutagenic agents. In Bioluminescence and Chemiluminescence: Basic Chemistry and Analytical Applications. Eds., M. DeLuCA \& W. McElroY, pp. 139 145, Academic Press, New York, 1981

9) Wecher, R. A. \& S. Scher: Bioassay procedures for identifying genotoxic agents using light emitting bacteria as indicator organisms. In Luminescent Assays: Perspective in Endocrinology and Clinical Chemistry. Eds., M. Serio \& M. Pazzagli, pp. 109 113, Raven Press, New York, 1982

10) Weiser, I.; S. Ulitzur \& S. YANNAI: DNA-damaging agents and DNA-synthesis inhibitors induce luminescence in dark variants of luminous bacteria. Mutat. Res. 91: 443 450, 1981

11) Nealson, K.: Autoinduction of bacterial luciferase: Occurrence, mechanism and significance. Arch. Microbiol. 112: 73 79, 1977 
12) Kopka, M. L.; C. Yoon, D. Goodsell, P. PJura \& R. E. Dickerson: The molecular origin of DNAdrug specificity in netropsin and distamycin. Proc. Natl. Acad. Sci. U.S.A. 82: 1376 1380, 1985

13) Naveh, A.; I. Potasman, H. Bassan \& S. Ulitzer: A new rapid and sensitive bioluminescence assay for antibiotics that inhibit protein synthesis. J. Appl. Bacteriol. 56: 457 463, 1984

14) Gale, E. F.; E. Cundliffe, P. E. Reynolds, M. A. Richmond \& M. J. Waring, Eds.: Inhibitors of nucleic acid synthesis. In The Molecular Basis of Antibiotic Action. pp. 258 386, John Wiley \& Sons Ltd., Great Britain, 1981

15) Scott, G. K.; K. Smith \& C. M. Thoreau: Comparative biochemistry of the cell envelopes of Photobacterium leiognathi and Escherichia coli. J. Gen. Microbiol. 129: 1583 1587, 1983 